\title{
Influence Of Servicescape, Customer Satisfaction, WOM, and Social Media to Consumer Loyalty (study case bali beach)
}

\author{
Syafrizal Helmi Situmorang \\ Dept. Of Management \\ Faculty Economy And Business \\ University of Sumatera Utara \\ Medan, Indonesia \\ shelmi09@gmail.com
}

\begin{abstract}
Indonesia have blessed with many beautiful natural scenery. This beautiful gift of nature must be kept to the best possible so that it can be enjoyed by many peopleand become a source of local income. The purpose of this study was to determine the influence of Servicescape, Customer satisfaction, Word of Mouth, and Social Media, to visiting interest local and foreign tourist to Bali Beach Lestari,Serdang Bedagai,North of Sumatra, Indonesia. The type of research is a causal associative research with data collection techniques in the form of questionnaires. Data was analyzed by using Regression Analysis. Data collection was made through questionnaires and interview. The results show that servicescape have positive impact and significant to customer satisfaction, Social Media, Word of Mouth, and customer loyalty. Customer satisfaction have positive impact and significant to, Social Media, Word of Mouth, and customer loyalty. This research also found Facebook is still most widely used social media by the respondents
\end{abstract}

Keywords - servicescape, customer satisfaction, word of mouth, social media, costumer loyalty

\section{Introduction}

The development of a tourist attraction is one efforts to improve the economy, social, and environment in North Sumatra. The various potential of the developed tourism object is potential natural attractions such as beaches. The beach is a favorite natural attraction to visit. Each holiday season arrives, various beaches are always filled with local tourists and foreign tourists. Coastal attractions are developed because the beach is no longer seen as a slum or just a place to catch fish, but has increased into a place for people enjoy the natural attractions, out of the daily routine, recreation and enjoy seafood.

In the area of Serdang Bedagai, Bali Lestari Beach is one of the interesting places to visit. Bali Beach Lestari often visited because of its uniqueness that uses typical Balinese. When first arrived at Bali Beach Lestari Medan, the tourist will be able to see the existence of a gate that has a shape similar to a gate in Bali. Not only that, there are also umbrellas accompanied by traditional Balinese music.Ornaments and symbols of Bali made the customers can feel the atmosphere as in the real island of Bali. Trouhgh servicescape of Bali concept, from ornamental decoration to the atmosphere presented. Bali Lestari beach has transformed into a busy destination visited by local tourists.

Servicescape is an organizational physical facility used to influence the feelings of consumers to be happy and positive emotion. [1] stated servicescape must produce fun and memorable vacation experiences begin with designing and constructing an attractive setting for tourists. [2] defined servicescape as the overall or total construct of environmental dimensions, rather than being a single component. The components of servicescape have been classified into three dimensions such as: 1) ambient conditions; (2) spatial layout and functionality; and (3) signs, symbols, and artifacts. One of the strategies undertaken by the tourist attraction is to improve servicescape to meet customer expectations. Servicescape can be used as a tool for making experience evaluations of customers easier [3].

Consumers who are impressed with servicescape, they will talk their positive experience with friends and family and recommend to visit. [4] indicated that image perceptions of tourists may change after having experienced a destination. [5] stated that perceived risks may decrease with the help of tourists' past experiences. Therefore, when the facilitative effect of servicescape components on experience and satisfaction.Customer satisfaction is at the heart of marketing. The ability to satisfy customers is vital for a number of reasons [6]. Researchers have also found a strong relationship between satisfaction and loyalty [7]. [8] stated aspects of servicescapes may have a strong influence on customers loyalty. 
Word of Mouth strategy is also very important to be implemented by a manager of coastal tourism. Word of Mouth (WOM) is the business of forwarding information to other consumers who are the positive intention. WOM is composed of "informal communications directed at other consumers about goods and services [9]. [10] stated that WOM "includes relating pleasant, vivid, or novel experiences; recommendations to others. According to [11], Word of Mouth Marketing is giving people a reason to talk about you and making it easier for the conversation to take place.

Now, Social Media have changed marketing strategies, revolutionized the way businesses communicate with their consumers, moving toward a more mutually beneficial, personalized, trusted and transparent approach to relationship building [12]. Along with the development of information and communication technology, many media used to promote tourism is social media. Trough social media, consumers can share their experiences by posting text-oriented information combined text and image information. [13] have been grouped to key elements of Social such as Media research (social presence, media richness) and social processes (self-presentation, selfdisclosure).

This study aims to increase the current level of theoretical understanding about the important role of servicescape in customer satisfaction and loyalty and highlighting the practical benefits of social media and Word of Mouth. In this regard, the study was designed to contribute to the theory of Service Marketing and Social Media tourism development research in north Sumatra, as well as empirical contributions through the provision of empirical insights into contemporary services.Through operationalization a measure of all variable, it is intended to provide methodological contributions as well as practical implications.

\section{LITERATURE REVIEW}

\section{A. Servicescape}

According to [14], the discussion of servicescape has been widely practiced by various researchers. but the term of servicescape has many names such as "the physical environment", "atmospherics", "marketing environment", "economic environment", "interactive theatre", "health scares", "environmental psychology" store environment", "service environment", "social-servicescape". [15] first coined the term servicescape as the environment wherein the service is assembled for customers and where buyer and seller interact with each other.

[2] explained that servicescape is used to describe the dimensions of physical surroundings, including all objective physical factors that can be controlled by a firm to enhance or constrain the actions of employees and customers. Bitner introduced a framework with the three following dimensions: (1) ambient conditions; (2) spatial layout and functionality; and (3) signs, symbols, and artifacts. Servicescape can be used as a tool for making experience evaluations of customers easier. [16] suggested that tangible and intangible components are essential for creating service experiences and should thus be included in servicescape. [17] suggested considering social aspects of servicescape. The scope of social servicescape to include customer-tocustomer influences. [18] explored socially symbolic servicescape to examine the cultural influence on servicescape.

\section{B. Word of Mouth and Social Media}

WOM intention is an important tool for international businesses and regions [19] because businesses often cannot bring their products and services, such as destinations or hotel businesses, to the customers doorstep, as product and service production is synchronous and on-site, although they try to advertise themselves in the best way possible. [20] define WOM as shared personal experiences and opinions among friends, colleagues or relatives. In addition, [21] have pointed out that WOM is one of the most effective tools in the service sector. Thus, it can be stated that positive behavioral intentions of people who have experienced a business are quite important for the hotel industry.

[22] Argue that traditional WOM communication consists of verbal exchanges with friends or relatives in face-to-face situations. The growth of the Internet and social media, eWOM has become the power to reach more people and is therefore perceived as more influential. [23] suggest that eWOM is more influential than traditional WOM because of certain unique features, such as convenience, speed, one-to-many, many-to-many and the absence of faceto-face interaction. [11] mentions that there are 5 elements (Five Ts) needed for word of mouth in order to spread such as Talkers, Topics, Tools, Taking Part and Tracking. Trough WOM, customers create value become-creators and active participants in the value-creation process rather than passive receivers of information.

Social media has revolutionized the way people to connect, communicate, interact, search for opinion, share experiences, and creates a group of people who share information and content. [24] confirmed that Social Media is particularly important to the consumer, "where communication is more emotional than informational" and where consumers are more interested in collecting and reviewing information during their decision-making process. Social Media plays an important role in tourist three-step travel planning process: pre-trip, during-trip and post-trip 
[25]. Social Media has influenced the consumer's decisionmaking process [26]. Social media has created valuable opportunities for eWOM conversations.

\section{Customer Satisfaction and Customer Loyalty}

In the service-marketing literature, "Customer satisfaction" has been posted as an effective post-purchase evaluation of the total experience of a service encounter, with an antecedent role being played by the more cognitively oriented construct of service quality" [27] Customer satisfaction refers to a customer's evaluation of products and services after purchase as opposed to their expectation [28]. Customer satisfaction is a complex human process of psychological and physiological factors, it is not merely an effective phenomenon but is also a cognitive process [29]. Previous research asserts that individual service quality elements have a positive effect on both customer satisfaction and customer loyalty. Servicescape also referred to as the service encounter has been shown to increase customer satisfaction across industries [30]. According to [31], the conceptualization and measurement of servicescape have relative importance to predict customer satisfaction.

[32] defined customer loyalty as ". . . a deeply held commitment to rebuy or repatronize a preferred product/service consistently in the future, causing repetitive same brand or same brand-set purchasing, despite situational influences and marketing efforts". Customer loyalty is very important for companies in business competition era. Companies that are able to develop and maintain consumer loyalty will achieve long-term success [33]. Loyal customers are also thought to act as information channels, informally linking networks of friends, relatives and other potential customers to the organization [34]. Study by [35]. companies must continuously improve any aspect (physically and emotionally) in customer interaction, so the customer will be more loyal, willing to repurchase/revisit and recommend those brand/place to their friends or relatives.

\section{METHODOLOGY}

The survey consisted of five variable (1) servicescape (2) Customer satisfaction (3) word of mouth (4) Social Media (5) Customer loyalty. Prior to starting the first part of the survey, participants were asked whether they have social media, Only those who had confirmed that they have social media were eligible to complete the survey. Five benefit variables (servicescape, sustomer satisfaction, word of mouth, Social Media and Customer loyalty) were adapted from [2], [13], [11], [28], [32] All items variable were measured using a 5-point Likert-type scale ranging from 1 (strongly disagree) to 5 (strongly agree). The data were analyzed using descriptive statistics such as mean and standard deviation, and path analysis. Path analysis was used to analyze the relationship between servicescape, customer satisfaction, Word of Mouth, Social Media and customer loyalty.

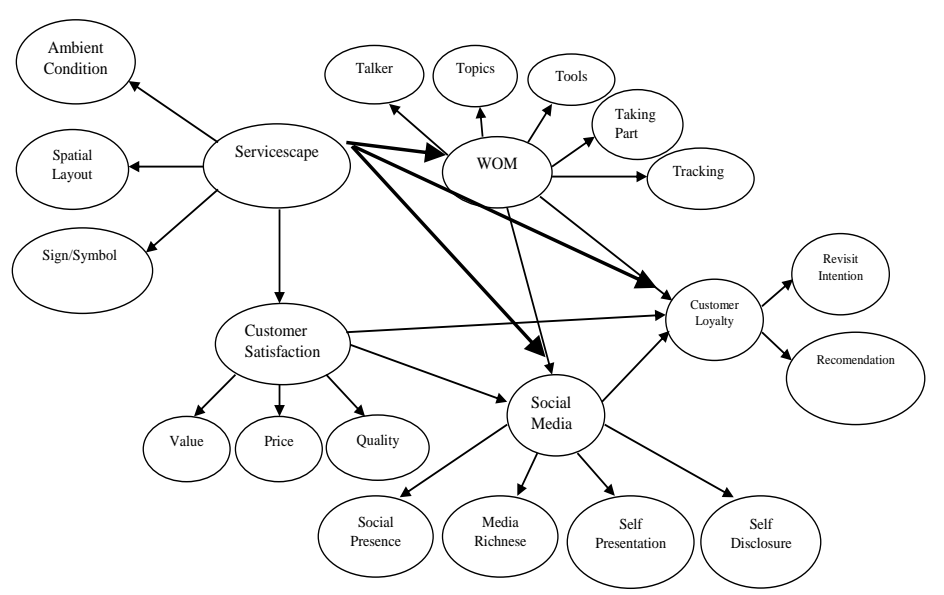

Fig 1 Conceptual Framework

\section{FINDING AND RESULT}

\section{A. Demographic responses}

Referring to The Table, Gender Group of Man respondents as much as 60 and women gender respondents were 40. Group Age, 17-21year (19\%) 22-30 year (34\%) and $31-40(23 \%)$ 41-50 year (16\%), above 50 year $(8 \%)$. Group occupation, student (22\%), Government employees (14\%), Private employees (24\%), Businessman (23\%), Housewife $(11 \%)$, others $(6 \%)$. For Social Media Usage, have more than one social media, Facebook (92\%), Instagram (65\%), What Apps ( 80\%), Line (42\%), Path $(22 \%)$.

Table 1. Descriptive Statistics

\begin{tabular}{|c|c|c|}
\hline Variable & Mean & Std. Deviation \\
\hline Servicescape & 3,69 & 3,46 \\
\hline Satisfaction & 3,82 & 2,08 \\
\hline WOM & 3,46 & 3,70 \\
\hline Socmed & 3,96 & 3,46 \\
\hline Loyalty & 4,25 & 1,72 \\
\hline
\end{tabular}

From table 2, it can be seen mean variable Servicescape, Customer satisfaction, WOM and Social Media in range (scale 3,4-4.2). it means all variable is Good. Only variable Loyalty in range (scale 4.21-5.00), it means very good/ high loyalty. 
Table 2. Result

\begin{tabular}{|c|c|c|c|c|c|c|c|}
\hline From & To & $\begin{array}{c}\text { Standar } \\
\text { dized } \\
\text { Coeffici } \\
\text { ents }\end{array}$ & T Test & $\mathrm{R}$ & $\mathrm{R}^{2}$ & $\mathrm{E}$ & $\begin{array}{l}\text { Hypotes } \\
\text { is } \\
\text { Testing }\end{array}$ \\
\hline \multirow{4}{*}{$\begin{array}{l}\text { Service } \\
\text { scape }\end{array}$} & WOM & .425 & 4.238 & .425 & .180 & 0.82 & $\begin{array}{c}\text { Support } \\
\text { ed }\end{array}$ \\
\hline & $\begin{array}{l}\text { Satisfac } \\
\text { tion }\end{array}$ & .851 & 16.033 & .851 & .724 & 0,276 & $\begin{array}{c}\text { Support } \\
\text { ed }\end{array}$ \\
\hline & $\begin{array}{l}\text { Social } \\
\text { Media }\end{array}$ & .394 & 4.246 & .394 & .155 & 0,845 & $\begin{array}{l}\text { Support } \\
\text { ed }\end{array}$ \\
\hline & Loyalty & .365 & 3.885 & .365 & .133 & 0,818 & $\begin{array}{l}\text { Support } \\
\text { ed }\end{array}$ \\
\hline \multirow{3}{*}{$\begin{array}{c}\text { Satisfa } \\
\text { ction }\end{array}$} & WOM & .547 & 6.473 & .547 & .300 & 0,700 & $\begin{array}{c}\text { Support } \\
\text { ed }\end{array}$ \\
\hline & $\begin{array}{l}\text { Social } \\
\text { Media } \\
\end{array}$ & .506 & 5.811 & .506 & .256 & 0,744 & $\begin{array}{l}\text { Support } \\
\text { ed }\end{array}$ \\
\hline & Loyalty & .522 & 6.061 & .522 & .273 & 0.727 & $\begin{array}{c}\text { Support } \\
\text { ed }\end{array}$ \\
\hline \multirow[t]{2}{*}{ WoM } & $\begin{array}{l}\text { Social } \\
\text { Media }\end{array}$ & 0,702 & 9,745 & 0,702 & 0,492 & 0,508 & $\begin{array}{c}\text { Support } \\
\text { ed }\end{array}$ \\
\hline & Loyalty & 0,326 & 3,410 & 0,326 & 0,106 & 0,894 & $\begin{array}{l}\text { Support } \\
\text { ed }\end{array}$ \\
\hline $\begin{array}{l}\text { Social } \\
\text { Media }\end{array}$ & Loyalty & 0,200 & 2,019 & 0,200 & 0,04 & 0,96 & $\begin{array}{l}\text { Support } \\
\text { ed }\end{array}$ \\
\hline
\end{tabular}

Referring to The Table, it can be seen, Servicescape has positive impact and significant to Wold of Mouth ( $\mathrm{P}$ value< 0,05), the meaning of that, if World of Mouthincreases, then servicescape tend to increase. Based on interviews, Bali Beach Lestari is used as a favorite photo location of customers. they feel impressed with the beach atmosphere, and presence of interesting photo spots such as sign and symbol of Bali ethnic, open area with colorful umbrellas (Feels like being in an umbrella festival), or moment photo twilight time. They will share and upload their photos. Customers will also recommend a visit to Bali beach through social media. The primary purpose of sharing pictures for most people is that they want to show it to their friends or relatives. These results are in line with the studied by [36] that servicescape components had a positive effect on word-of-mouth (WOM) and re-visiting.

From the table it can be seen, servicescape has a positive impact and significant to Social Media (P-value < $0,05)$, meaning that if Servicescape increases, then Social Media tend to increase. This result shows the service provider should recognize that the servicescape may become a crucial component of the marketing strategy. In location beach, where customers may spend minimum upwards of two hours, enjoying servicescape may determine to a large extent the degree of memorable experience. A study by [37] traveler community are likely to be involved with activities such as searching for information about servicescape, sharing service experiences with other members, and communicating with the service provider.

From the table, it can be seen Servicescape also have a positive impact and significant to Customer Satisfaction ( $\mathrm{P}$ value $<0,05)$ and Customer loyalty (P-value $<0,05)$ meaning that if servicescape increase, then Customer Satisfaction and loyalty tend to increases. Customers are satisfied because of the time and money they spent less than the value and experience they receive. Studied [38] consider the effect of the servicescape (tangibles) and the intangibles in its impact on service quality. [39] suggest that the physical elements of the service are of greater importance in determining customer evaluations on overall satisfaction than interactive features of service.

This study also found when customer satisfaction increase, customer loyalty tends to increase. From the table, It can be seen Customer Satisfaction have a positive impact and significant to customer loyalty ( $\mathrm{P}$ value $<0,05)$. If customers loyal, they will revisit Bali beach, recommend to other people through WOM or Social Media. This study is in line with the views of some of the earlier researchers such as [40]; [41] that stated satisfaction with a service is an important determinant of customer loyalty. They will more loyal and committed brand or firm. Loyal customers had a lower probability to switch [42]

According to [43]. If the perceived performance of the product or service exceeds the expectations of the customer, then the result is positive disconfirmation and if the performance of the product is below expectations, it leads to negative disconfirmation. [44] stated Positive disconfirmation allows for positive word of mouth, and negative disconfirmation results in discontinuity and negative word of mouth. Referring to The Table, it can be seen, Customer Satisfaction also have positive impact and significant to Word of Mouth $(\mathrm{P}$-value $<0,05)$

Referring to the table, it can be seen, customer satisfaction increases social media tend to increase. Social media also have a positive impact on customer loyalty. According to [45]. Social media has changed consumer access to, and engagement with information. Social media give opportunities for creating services to enrich tourist experiences and support the temporary sociality and network building that can arise during tourist activities. [46] point out participation through social media as a community-building feature of large travel community memberships. Example, The travel blog like traveloka.com or travel advisor makes it easy for tourist sharing experiences. According to [47] Social media marketing have effect online participation. This opinion is in line with the results of this research that social media have a positive impact and significant to customer loyalty.

\section{CONCLUSION}

As expected, results indicated servicescape have a positive impact and significant to customer satisfaction, word of mouth, social media and customer loyalty. It means servicescape becomes an important factor in the management of coastal tourism. When customers enter a service environment in the beach, they will search and pay 
attention to surveillance photo spot inside the servicescape. It allows Bali beach to professionally showcase its brand and stand out from other beaches. Service providers cannot neglect it; but rather, must guarantee it. Remember, they impress, they will happy and then satisfy. They talk and promote to other people about their experience and enjoy. They will share the happy moment and upload the photo to social media. It will increase the brand awareness of location service. People will interest, search more information (tracking) about location, and then come to location (check-in). As our result, customer satisfaction also has positive impact and significant to word of mouth, social media and customer loyalty. Social media give to the service provider the opportunity engage with customers. So marketing manager should understand the impact social media in develop integrated marketing strategist. The result supported that Word of mouth and social media have a stronger effect on customer loyalty.

Clearly, the current study is not conclusive; however, it is the first to suggest that servicescape is important to the atract customer and increase customer satisfaction. This small-scale research provides a limited analysis of a broader typology. Further analysis of the current data is possible and will be conducted. In addition, efforts are underway to include additional beach and respondent in the sample.

\section{References}

[1] Brownell, J. (2014), Managing Context to Improve Cruise Line Service Relationships. Center for Hospitality Research Reports.

[2] Bitner, M.J. (1992), "Servicescapes: the impact of physical surroundings on customers and employees", Journal of Marketing, Vol. 56 No. 2, pp. 57-71

[3] Namasivayama, K. and Lin, I.Y. (2008), "The servicescape", in Jones, P. (Ed.), Handbook of Hospitality Operations and IT, Butterworth-Heinemann, Oxford, pp. 43-62.

[4] Fakeye, P. and Crompton, J. (1991), "Image differences between prospective, first-time, and repeat visitors to the lower Rio Grande Valley", Journal of Travel Research, Vol. 22 No. 4, pp. 3-13.

[5] Sönmez, S.F. and Graefe, A.R. (1998), "Determining future travel behavior from past travel experience and perceptions of risk and safety", Journal of Travel Research, Vol. 37 No. 2, pp.172-177.

[6] Andaleeb, S.S and Conway, C. (2006) "Customer satisfaction in the restaurant industry: an examination of the transaction-specific model", Journal of Services Marketing, Vol. 20 Issue: 1, pp.3-11,

[7] Szymanski, D.M. and Henard, D.D. (2001), "Customer satisfaction: a meta-analysis of the empirical evidence", Journal of the Academy of Marketing Science, Vol. 29 No. 1, pp. 16-35

[8] Foxall, G.R. and Yani-de-Soriano, M.M. (2005), "Situational influence on consumers' attitude and behaviour", Journal of Business Research, Vol. 58, pp. 518-25.
[9] Westbrook, R.A. (1987), "Product/consumption-based affective responses and postpurchase processes", Journal of Marketing Research, Vol. 24 No. 3, pp. 258-270

[10] Anderson, E.W. (1998), "Customer satisfaction and word of mouth", Journal of Service Research, Vol. 1 No. 1, pp. 5-17

[11] Sernovizt, A. (2009). Word of Mouth Marketing: How Smart Companies People Talking. Chicago: Kaplan Publishing.

[12] Minazzi, R. (2015), Social Media Marketing in Tourism and Hospitality, Springer, Heidelberg

[13] Kaplan and Haenlein. (2010). Users of the world, unite! The Challenges and opportunies of Social Media. Business Horizons, 59-68.

[14] Harris, L.C and Ezeh,C. (2008) "Servicescape and loyalty intentions: an empirical investigation", European Journal of Marketing, Vol. 42 Issue: 3/4, pp.390-422

[15] Booms, Bernard H. and Mary J. Bitner,1981. Marketing Strategies and Organization. Structures for Services Firms, " in Marketing of Services, .JHDonnelly and W.R.George, eds. Chicago, American Marketing, 47-51.

[16] Hoffman, K.D. and Turley LW. (2002), "Atmospherics, service encounters and consumer decision making: An integrative perspective", Journal of Marketing Theory \& Practice, Vol.10 No.3, pp.33-47.

[17] Tombs, A.G. and McColl-Kennedy, J.R. (2003), "Socialservicescape conceptual model", Marketing Theory, Vol.3 No.4, pp.447-475

[18] Rosenbaum, M.S. and Massiah, C. (2011), "An expanded servicescape perspective", Journal of Service Management, Vol. 22 No.4, pp.471-490

[19] Bone, P.F. (1995), "Word-of-mouth effects on short-term and long-term product judgments", Journal of Business Research, Vol. 32 No. 3, pp. 213-223.

[20] Sun, T., Seounmi, Y., Wu, G. and Kuntaraporn, M. (2006), "Online word-of-mouth (or mouse): an exploration of its antecedents and consequences", Journal of ComputerMediated Communication, Vol. 11 No. 4, pp. 1104-1127

[21] Ha, J. and Jang, S. (2010), "Perceived values, satisfaction, and behavioral intentions: the role of familiarity in Korean restaurants", International Journal of Hospitality Management Vol.29No.1,pp.2-13.

[22] Bickart, B. and Schindler, R. (2001), "Internet forums as influential sources of consumerinformation", Journal of Interactive Marketing, Vol. 15 No. 3, pp. 31-52.

[23] Phelps, J.E., Lewis, R., Mobilio, L., Perry, D. and Raman, N. (2004), "Viral marketing or electronic word-of-mouth advertising: examining consumer responses and motivations to pass along email", Journal of Advertising Research, Vol. 45 No. 4, pp. 333-348

[24] Cervellon, M.C. and Galipienzo, D. (2015), "Facebook pages content, does it really matter? Consumers' responses to luxury hotel posts with emotional and informational content", Journal of Travel \& Tourism Marketing, Vol. 32 No. 4, pp. 428-437.

[25] Leung, D., Law, R., van Hoof, H. and Buhais, D. (2015), "Social media in tourism and hospitality: a literature review", Journal of Travel and Tourism Marketing, Vol. 30 Nos 1/2, pp. 3-22.

[26] Park, S. and Allen, J. (2013), "Responding to online reviews: problem solving and engagement in hotels", Cornell Hospitality Quarterly, Vol. 54 No. 1, pp. 64-73.

[27] Cronin, J.J. Jr, Brady, M.K. and Hult, T.M. (2000), "Assessing the effects of quality, value, customer satisfaction on consumer behavioral intentions in service environment", Journal of Retailing, Vol. 76 No. 2, pp. 193-218. 
[28] Oliver, R. L. (1997). Satisfaction: A Behavioral Perspective on the Consumer. New York, NY: McGraw-Hill.

[29] Oh, H. and Parks, S.C. (1997), "Customer satisfaction and service quality: a critical review if the literature and research implications for the hospitality industry", Hospitality Research Journal, Vol. 20 No. 3, pp. 35-64.

[30] Pareigis, J., Edvardsson, B. and Enquist, B. (2011), "Exploring the role of the service environment in forming customer's service experience", International Journal of Quality Service and Service Sciences, Vol. 3 No. 1, pp. 110124

[31] Pantouvakis, A. (2010) "The relative importance of service features in explaining customersatisfaction: A comparison of measurement models", Managing Service Quality: An International Journal, Vol. 20 Issue: 4, pp.366-387,

[32] Oliver, R.L. (1999), "Whence consumer loyalty?", Journal of Marketing, Vol. 63, pp. 33-44.

[33] Situmorang, S.H., Annisa,M., Hadian, A. (2016) GenerasiMillenial : Net Promoter Score dan Net Emotional Value, confrence paper FEB USU, Medan

[34] Shoemaker, S. and Lewis, R.C. (1999), "Customer loyalty: the future of hospitality marketing",International Journal of Hospitality Management, Vol. 18, pp. 345-70

[35] Situmorang, S.H.(2017) Gen C and Gen Y : Experience, Net emotional Value and Net Promoter Score, Advances in Social Science, Education and Humanities Research (ASSEHR), volume 81, Pp. 259-265

[36] Durna, U., Dedeoglu,B.B., Balikçioglu,S. (2015) "The role of servicescape and imageperceptions of customers on behavioral intentions in the hotel industry", International Journal ofContemporary Hospitality Management, Vol. 27 Issue: 7, pp.1728-1748,

[37] Wang, Y. C., \&Fesenmaier, D. (2004a). Towards understanding member's general participation in and active contribution to anonline travel community. Tourism Management, 25 (6), 709-722

[38] Kang, G. and James, J. (2004), "Service quality dimensions: an examination of Gronroos's service quality model", Managing Service Quality, Vol. 14 No. 4, pp. 266-77.

[39] Pantouvakis, A. And Lymperopoulos, K. (2008) "Customer satisfaction and loyalty in the eyes of new and repeat customers: Evidence from the transport sector", Managing Service Quality: An International Journal, Vol. 18 Issue: 6, pp.623-643,

[40] Bloemer, J.M.M. and Poiesz, T.B.C. (1989), "The illusion of consumer satisfaction", Journal ofConsumer Satisfaction, Dissatisfaction and Complaining Behavior, Vol. 2, pp. 43-8.

[41] Dick, A.S. and Basu, K. (1994), "Customer loyalty: toward an integrated framework", Journal of the Academy of Marketing Science, Vol. 22 No. 2, pp. 99-113.

[42] Bloemer, J.M.M. and Karper, H.D.P. (1995), "The complex relationship between consumersatisfaction and brand loyalty", Journal of Economic Psychology, Vol. 16, pp. 311-29.

[43] Jamal, A., \&Naser, K. (2002). Customer satisfaction and retail banking: an assessment of some of the keyantecedents of customer satisfaction in retail banking. International Journal of Bank Marketing, vol 20,146-160.

[44] Sayani, H. (2015). Customer satisfaction and loyalty in the United Arab Emirates banking industry. International Journal of Bank Marketing, 33, 351-375.

[45] Bødker, M., and Browning,D. (2013) "Inspiring Design: SocialMedia from the Beach" In Tourism Social Media: Transformations in Identity, Community and Culture,. Tourism Social Science Series, Volume 18, pp.107-131
[46] Wang, Y. C., \&Fesenmaier, D. R. (2004b). Modeling participation in an online travel community. Journal of Travel Research,42 (3), 261-270

[47] Al-Msallam, S and Alhaddad, A (2016) The Effects of Social Media Marketing In the Hotel Industry: Conceptual Model for Development of an Effective OnlineCommunity, international Journal of Business and Management Invention, Volume 5 Issue $7 \mathrm{PP}-01-12$ 